\title{
HURDLES AND OPPORTUNITIES FOR WOMEN CAREER IN STARTUPS
}

\author{
OBSTÁCULOS E OPORTUNIDADES PARA CARREIRA FEMININA EM STARTUPS
}

Recebido em 03.04.2020 Aprovado em 12.06.2020

Avaliado pelo sistema double blind revien DOI: https://doi.org/10.12712/rpca.v14i2.41290

\author{
Manoel Bastos Gomes Neto \\ neto26bastos@gmail.com \\ Universidade Federal do Cariri - Juazeiro do Norte/Ceará, Brasil \\ https://orcid.org/0000-0003-4400-5877
}

\section{Lucas Emmanuel Nascimento Silva}

lucasemmanuel1998@gmail.com

Universidade Federal do Cariri - Juazeiro do Norte/Ceará, Brasil

https://orcid.org/0000-0001-7767-1724

\section{Rebeca da Rocha Grangeiro}

rebecagrangeiro@ufca.edu.br

Universidade Federal do Cariri - Juazeiro do Norte/Ceará, Brasil

https://orcid.org/0000-0002-9292-2648

\section{Catherine Esnard}

catherine.esnard@univ-poitiers.fr

Centre de Recherche sur la Cognition et l'Apprentissage (CERCA)/Universidade de Poitiers - Poitiers/Nova

Aquitânia, França

https://orcid.org/0000-0003-4637-799X

\begin{abstract}
This qualitative study aims to identify and discuss the obstacles and opportunities for the women who work in leadership positions in startups. Ten women who work at eight startups in Fortaleza-CE were interviewed. The results showed that flexibility on work schedule and on job description, horizontal structure, incentives to hire women, and facility to occupy leadership positions are factors favorable to women career in startups. While negotiating with banks and customers and the difficulty of being heard at work meetings can be considered barriers to the development of women's careers. So, even if startups are less gendered organizations than the traditional ones, women are not immune to discrimination in this context.
\end{abstract}

Keywords: Gender and Work; Glass Wall; Opportunities and Barriers in startups.

\section{Resumo}

Esse estudo qualitativo tem como objetivo identificar e discutir os obstáculos e oportunidades para mulheres que atuam em cargos de liderança em startups. Foram entrevistadas dez mulheres que atuam em oito startups de Fortaleza- CE. Os resultados apontaram que flexibilidade de horário, estrutura horizontalizada, incentivos à contratação de mulheres e facilidade para ocupar cargos de liderança são fatores favoráveis ao crescimento profissional feminino em startups. Ao passo que negociação com bancos e clientes e dificuldade de serem ouvidas em reuniões podem ser considerados barreiras para o desenvolvimento da carreira feminina. Então, ainda que startups sejam organizações menos generificadas que as tradicionais, as mulheres não estão imunes à discriminação nesse contexto.

Palavras-chave: Gênero e Trabalho; Parede de vidro; Oportunidades e Barreiras em startups. 


\section{Manoel Bastos Gomes Neto, Lucas Emmanuel Nascimento Silva, Rebeca da Rocha Grangeiro e Catherine Esnard}

\section{Introduction}

Startups are innovative and technologically-based businesses that have a differentiated, less bureaucratic, and horizontal organizational structure, where employees have greater autonomy (Freeman \& Engel, 2017; Lopes Filho, Paiva, \& Lima, 2019). Since those enterprises aim to innovate and foster creativity, their organizational structure is more flexible and with less division of labor (Freeman \& Engel, 2007). The horizontal organizational structure of startups allows their members to have more autonomy and not to depend on a leader to distribute their tasks. In addition, startups are recognized for their flexibility with regard to time and place of working. Some jobs can be done at home-office and there is no obligation to work during the traditional business hours.

Therefore, such attributes can be configured as advantages for the development of the female career in startups, since in this new organizational model the abstract job loses its traditional meaning, allowing women to exercise functions that in a traditional organization would mostly be occupied by men. Furthermore, the inherent flexibility in the context of startups is an advantage for women, who are able to manage their work time and private life, dimensions that are intimately interconnected to the women's life (O'Neil, Bilimoria, \& Hopkins, 2008). Hence, we propose an assumption that the intrinsic characteristics of the organizational model of startups are favorable to the development of the female career.

On the other hand, the analysis of the percentage of female founders of startups and those who are on the boards of these organizations also indicates a gender gap in this sector (Abstartups, 2020). When it comes to data on startups strongly linked to technology, the percentage of female founders is even lower (17\%), according to Ebricks Digital (2014).

Theoretical discussions on female underrepresentation in certain positions call "Glass Walls" the challenges faced by women in high hierarchical positions, which prevent them from reaching certain positions or sectors in the organization (Santos, Carvalho Neto, Caeiro, Versiani, \& Martins, 2016). Therefore, women end up in positions that have historically been perceived as female. The main barriers that contribute to the development of this phenomenon are family, friends, co-workers, customers, suppliers, and funders (Cursino \& Carvalho Neto, 2015; Santos et al., 2016). In this sense, Kuschel, Lepeley, Espinosa, and Gutiérrez (2017) identified that women in startups are discriminated by customers, suppliers, and investors. Investor gender biases are critical for women, for access to funding is crucial to the startup's success and growth in all its development stages (Welsh, Kaciak, \& Thongpapanl, 2016; Kanze, Huang, Conley, \& Higgins, 2018). Male ventures are more funded than female ones (Brooks, Huang, Kearney \& Murray, 2014), and the amount of funding received by men are higher than those received by women (Kanze et al., 2018). With regard to investments, the female advantage is limited to crowdfunding, which is low-value funding, where stereotypes, like being careful and reliable, lead investors to choose projects funded by women (Johnson, Stevenson, \& Letwin, 2018).

Although it is believed that intrinsic characteristics of startups are favorable to the professional development of women, it is observed that they still suffer gender discrimination that act as barriers or obstacles to their career progress in these organizations. This is the second assumption of this study and it is based on the fact that startups are inserted in a society permeated by gender inequality and maintain relations with gendered organizations (Acker, 1990), since the interactions of these professionals with customers, suppliers, investors and even with people in their private circle, build obstacles for their professional development.

Given the peculiarities inherent to the organizational model of startups, the research objective is to identify and discuss the obstacles and opportunities that have emerged for the career of women who work in leadership positions in startups. The most recent theoretical reviews on gender and career did not identify studies on women working in startups (Fraga, Gemelli, \& Rocha-de-Oliveira, 2019), which indicates the originality of this study and its usefulness in providing relevant information for the 
development of policies to expand female participation in these organizations, especially in traditionally non-female areas. In addition to the novelty, regarding this, the theme in the national literature, the relevance of this research resides in the need to discuss gender issues in new organizational contexts, at first less discriminatory and more friendly to female performance.

Reflecting on the current scenario of the COVID-19 pandemic, some issues have been discussed concerning the female career and that can harm the advances that women achieved over all this time. Firstly, although unemployment rates are rising everywhere, in the United States, in April, women's unemployment rate $(16.2 \%)$ was higher than the men's one $(13.5 \%)$, which can be explained by the overrepresentation of women in the service sector, highly affected by this crisis (Micklas, 2020). In Brazil, in the first three months of 2020, the rate of women unemployed was 39,4\% higher than of the men's (Agência Estado, 2020). Second, this health crisis brought even closer the work and home life dimensions that are already highly interconnected in women's life (O'neil et al., 2008). Therefore, working mothers are being particularly affected by these circumstances, and even as the economy reopens, those women will have to work part-time or to exit the job market given that the gradual reopening of schools and day care centers will not decreased their responsibility at home (Cohen \& Hsu, 2020). Although social and economic setbacks and inequalities are being faced by men and women, women are more highly affected by them (Donner, 2020), thus, women's advancement in the workplace is at risk (Donadio, 2020). Nonetheless, this crisis helps to put on the spotlight the female leadership in politics, because they are being able to deal better with the pandemic and are showing a more effective response (Taub, 2020).

Given the issues that women face in the workplace and the additional challenges that the pandemic and its consequences will impose to their career, this paper is important in presenting the startup as an organizational structure more flexible that can improve the opportunities for women and by presenting the challenges that women still face in this environment, being useful to the development of managerial and public policies to improve equality in the workplace.

\section{Horizontal gender segregation and the glass walls}

Sociocultural characteristics can assert gendered organizational contexts, building and reinforcing stereotypes about female and male competences (Olinto, 2011). These mechanisms influence the decision-making process of men and women in choosing their careers, creating and perpetuating barriers in the world of work. Social constructions based on gender role differences limit women's life and career prospects, in addition to structuring two types of segregation, horizontal and vertical (Lombardi 2006, 2017; Olinto, 2011; Gauche, Verdinelli, \& Silveira, 2013).

Vertical segregation refers to the existence of obstacles, visible or invisible, imposed on women that limit their hierarchical growth within organizations (Lombardi 2006, 2017). These forces tend to keep women at the lowest levels of the organizational pyramid. The glass ceiling metaphor has been widely used to show this gender segregation (Smith, Caputi, \& Crittenden, 2012), which imposes subtle and invisible barriers, but at the same time, are very efficient in hindering and even preventing female career advancement (Morrison \& Von Glinow, 1990), so that the highest management positions are still predominantly occupied by men (IBGC, 2015). The Brazilian Association of Startups - Abstartups (2019) reiterates this information, by mapping more than 12,000 organizations in this ecosystem, confirming that only $15.7 \%$ of the enterprises were founded or co-founded by women.

Horizontal segregation is based on socially acceptable parameters for women and leads them to make career choices based on stereotypes and gender differences. This mechanism encourages women to follow different paths of action from those defined almost exclusively for men (Gauche et al., 2013). The phenomenon of horizontal segregation is perpetuated mainly through the actions of families and schools, 


\section{Manoel Bastos Gomes Neto, Lucas Emmanuel Nascimento Silva, Rebeca da Rocha Grangeiro e Catherine Esnard}

which influence girls to choose their careers oriented to professions and areas typically female (Olinto, 2011).

In Brazil, particularly, there is no gender parity in the STEM (Science, Technology, Engineering, and Mathematics) and the uneven distribution between genders grows even more in high hierarchical positions (Olinto, 2011). Hardey (2019) analyzed the diffusion of the existence of male culture in technological cities, spaces predominantly occupied by men, and identified gender discrimination and female segregation in activities that require technological skills. The presence of these obstacles reinforces the existence of the glass wall effect (Santos et al., 2016).

The glass wall is still a little-studied phenomenon (Smith et al., 2012) that prevents women, who occupy hierarchically high positions, from accessing certain sectors or areas of the organization (Santos et al., 2016) and keeps them in occupations that are traditionally seen as female (Sabharwal, 2015, Guillaume \& Pochic, 2009). According to Miller, Kerr, and Reid (1999), this phenomenon deals with the existence of barriers that hinder female horizontal mobility in high positions in the organization, for two main reasons: i) the organizational culture; ii) skills valued in different ways, depending on the environment. This barrier does not refer to an impediment to vertical mobility since women are already in hierarchically high positions, but it is about obstacles to horizontal mobility at the top of the hierarchy (Santos et al., 2016). There are three types of glass wall faced by women.

The first one concerns the family (partners who do not encourage financial independence and social recognition). An entrepreneurial career maximizes women's financial independence and guarantees greater social recognition. In some cases, these two factors cause discomfort to the partner of the entrepreneurs who have difficulties in dealing with the fact that they have relationship networks beyond the family and might have financial gains superior to those obtained by them (Santos et al., 2016). Cursino and Carvalho Neto (2015) support the existence of the barrier by declaring that husbands do not accept, feel devalued, and do not support their wives when they perceive them as independent and professionally successful since culturally, the role of men it is to be the provider of family support.

The second wall is established by customers, suppliers, and financiers, with whom the entrepreneur must relate in order to maintain her business working properly. Santos et al. (2016) state that customers and suppliers are surprised when they realize that it is a woman who leads the enterprise and that the entrepreneurs declare that they tend to adopt more masculine traits to guarantee a better negotiation. In addition, they need to constantly prove their skills and abilities. In the context of funding, it appears that women are less likely to receive bank funding and that funders expect better qualifications from women entrepreneurs than from men (Bigelow, Lundmark, McLean Parks, \& Wuebker, 2014), in addition to the subtle discrimination that excludes women from access to capital (Coleman \& Robb, 2009).

Coworkers, friends, other entrepreneurs, and acquaintances are responsible for introducing the third type of barrier to women entrepreneurs. This group includes all individuals who directly or indirectly assist in the construction and strengthening of gender stereotypes, contributing to segregation. This wall is linked to the ingrained "macho culture" that determines which tasks must be performed by women and men in the workplace.

\section{Method}

This section presents the methodological procedures used for conducting the field research. The study has an exploratory nature, with a qualitative approach, aiming to identify and discuss the obstacles and opportunities that have emerged for the career of women who work in leadership positions in startups. 


\section{Instrument}

To perform the data collection process, we chose the semi-structured interview. The interview protocol was developed from careful readings of previous studies on gender, leadership, and female participation in the labor market and leadership positions in organizations. According to the defined objective and the concepts acquired from the readings, the interview protocol was divided into five sections: i) personal information (sex, age, training, professional trajectory, motivations for working in startups); ii) information about startups (time of existence, city of origin, number of employees, board of directors, sector); iii) participation in startup (questions focused on the skills needed to work in organizations of this model, group participation and events, evaluation of female participation); iv) factors that favor professional progress (issues related to government incentives, educational institutions and incubators, quota policies, flexibility, materials); v) barriers (difficulties at the beginning of the career, in negotiations with banks, financial institutions, customers, co-workers).

\section{Participants}

The interviewed participants were professionals in leadership positions who work in Startups in the city of Fortaleza, capital of the State of Ceará. This territorial cut was defined because Fortaleza occupies the ninth place in the ranking of Brazilian cities with the highest absolute number of Startups (Matos, 2017) and the third place in the Northeast, behind only Salvador and Recife (ABstartups, 2019).

10 professionals from 8 different companies were interviewed. Regarding the field of activity of the selected companies, we found that two startups operate in the area of education, two in software development, one in the area of health, one in the field of application, one that performs consulting for other startups and one managing the customer/company relationship. There is a variation in the foundation period from 2 months to 6 years. Regarding the number of employees, only one startup did not have permanent employees, the others had between 3 and 69 people in its staff, varying due to size, time, and industry. Figure 1 presents the profile of the interviewees, their marital status, education, position, and time of experience in the organization. 
Figure 1. Characterization of the study participants

\begin{tabular}{|c|c|c|c|c|c|c|c|c|c|c|}
\hline \multirow{2}{*}{$\begin{array}{l}\text { Interviewee } \\
\text { Code }\end{array}$} & \multirow[b]{2}{*}{ Age } & \multirow{2}{*}{$\begin{array}{l}\text { Marital } \\
\text { Status }\end{array}$} & \multirow[b]{2}{*}{ Training } & \multirow[b]{2}{*}{ Job/Occupation } & \multirow{2}{*}{$\begin{array}{c}\text { Time } \\
\text { Workingin } \\
\text { the } \\
\text { Company }\end{array}$} & \multicolumn{5}{|l|}{ Startup } \\
\hline & & & & & & $\begin{array}{l}\text { Com } \\
\text { pany } \\
\text { Code }\end{array}$ & Sector & $\begin{array}{l}\text { Operati } \\
\text { ng } \\
\text { Time }\end{array}$ & $\begin{array}{c}\mathbf{N}^{\circ} \text { of } \\
\text { Employees }\end{array}$ & $\begin{array}{l}\text { Board of Directors } \\
\text { Composition }\end{array}$ \\
\hline E01 & 28 & Single & Psychology & $\begin{array}{l}\text { Human } \\
\text { Development } \\
\text { Coordinator }\end{array}$ & 10months & $\begin{array}{l}\mathrm{EMP} \\
01\end{array}$ & Education & Gyears & 69 & 5 menand 2 women \\
\hline $\mathrm{E} 02$ & 33 & Single & Social Services & $\begin{array}{l}\mathrm{CEO} / \text { Marketing } \\
\text { Director }\end{array}$ & $\begin{array}{c}2 \text { andahalf } \\
\text { years }\end{array}$ & $\begin{array}{l}\mathrm{EMP} \\
02\end{array}$ & $\begin{array}{l}\text { Virtual } \\
\text { Assistance } \\
\text { Soffware }\end{array}$ & 3 years & 10 & 2 womenand 2 men \\
\hline $\mathrm{E} 03$ & 25 & Single & $\begin{array}{l}\text { Systems and } \\
\text { Digital Media }\end{array}$ & $\begin{array}{l}\text { Innovation } \\
\text { Coordinator }\end{array}$ & $\begin{array}{c}\text { 3yearsand } 8 \\
\text { months }\end{array}$ & $\begin{array}{l}\mathrm{EMP} \\
03\end{array}$ & Education & 6years & 40 & 2 menand 1 woman \\
\hline $\mathrm{E} 04$ & 21 & Single & $\begin{array}{l}\text { Environment } \\
\text { aEngineering }\end{array}$ & QualitySupervisor & 3 years & $\begin{array}{c}\mathrm{EMP} \\
03\end{array}$ & Education & 6years & 40 & 2 menand 1 woman \\
\hline E05 & 26 & Married & Management & $\mathrm{COO}$ & 4years & $\begin{array}{l}\mathrm{EMP} \\
03\end{array}$ & Education & Gyears & 40 & 2 menand 1 woman \\
\hline $\mathrm{E} 06$ & 26 & Single & $\begin{array}{l}\text { Production } \\
\text { Engineering }\end{array}$ & $\mathrm{CEO}$ & 2years & $\begin{array}{c}\text { EMP } \\
04\end{array}$ & $\begin{array}{c}\text { Startups } \\
\text { Consulting }\end{array}$ & 3 years & $\begin{array}{l}\text { Don'thave } \\
\text { permanent } \\
\text { employees }\end{array}$ & 2 women \\
\hline $\mathrm{E} 07$ & 24 & Married & $\begin{array}{l}\text { Computer } \\
\text { Technican }\end{array}$ & $\begin{array}{l}\text { Directorof } \\
\text { Operations }\end{array}$ & 4years & $\begin{array}{c}\mathrm{EMP} \\
05\end{array}$ & $\underset{\text { Commerce }}{\mathrm{E}-}$ & 4 years & 20 & 5 menand 2 women \\
\hline E08 & 20 & Single & $\begin{array}{l}\text { Systems and } \\
\text { Digital Media }\end{array}$ & $\begin{array}{c}\text { Productand } \\
\text { CommunityLeader }\end{array}$ & $\begin{array}{c}\text { 2andahalf } \\
\text { years }\end{array}$ & $\begin{array}{c}\mathrm{EMP} \\
06\end{array}$ & $\begin{array}{c}\text { Software } \\
\text { Developmen } \\
\text { t }\end{array}$ & 2 years & 18 & 4 menand 1 woman \\
\hline E09 & 25 & Single & $\begin{array}{l}\text { Production } \\
\text { Engineering }\end{array}$ & $\mathrm{COO}$ & $\begin{array}{c}1 \text { andahalf } \\
\text { years }\end{array}$ & $\begin{array}{c}\mathrm{EM} 0 \\
7\end{array}$ & $\begin{array}{l}\text { Mobility } \\
\text { (Visually } \\
\text { Impained) }\end{array}$ & $\begin{array}{l}2 \text { anda } \\
\text { halfyears }\end{array}$ & 4 & 1 manand 1 woman \\
\hline E10 & 33 & Single & Marketing & $\mathrm{COO}$ & 2 months & $\begin{array}{c}\mathrm{EMP} \\
08\end{array}$ & $\begin{array}{l}\text { Customer } \\
\text { Rehationship } \\
\text { Maragement }\end{array}$ & $\begin{array}{c}2 \\
\text { months }\end{array}$ & 5 & 3 menand 2 woman \\
\hline
\end{tabular}


The interviewed professionals are between 21 and 38 years old. They are mostly single, only two are married. As for academic training, one has a technical level, two are in the process of graduation and the others have a college degree. The length of time in their current startup varies from 2 months to 6 years.

\section{Data collection and analysis procedures}

Initially, contact was made by phone and the objective of the research was presented, questioning her interest in participating and an appointment was scheduled to carry out the study. Before conducting the interviews, the objective of the research was again explained and the participants were asked to sign the consent form. This document guarantees the confidentiality and anonymity of the information, proving the free participation and ensuring compliance with the ethical criteria of research in Applied Social Sciences.

The interviews were conducted in January 2020, in person, valuing the contact, as well as the direct and prolonged observation of the researcher with the environment being studied. The average interview time was 48 minutes. Then, the more than eight hours of interviews were literally transcribed, constituting a material of 196 pages of transcripts. The data were analyzed using the technique of content analysis, seeking to understand the characteristics, structures, and meanings that are behind the message fragments, with the purpose of extracting significant elements from the corpus, allowing to test our assumptions (Flick, 2009).

\section{Results and discussions}

\section{Opportunities arising from the startups peculiar organizational structure}

Startups are ventures based on innovation and technology (Freeman \& Engel, 2007), they are structurally less bureaucratic, allowing greater flexibility in time and function to their collaborators, also they are culturally more autonomous environment. These characteristics are reported by all respondents as benefits for working in this business model. E03 says: “(...) I really like this ... not being inside a box, [...] not arriving every day and doing the same thing, you know! I notice this a lot in the startup environment, I think that's why I liked it so much". The project-based work in startups permits the contact with many kind of different activities, what make the work challenger at the same time that improve new knowledges and abilities.

Yet, although none of the companies had a policy for mothers-workers, the interviewees highlighted the more flexible culture also for future mothers:

\footnotetext{
"there would be no problems with that, (...) we would do more to try to help more, ... if the person say '(...) I will be home office because it is my first year and I prefer to be closer to my child' and it wouldn't be a problem if it didn't hinder the job in any way" (E 02)
}

Another aspect narrated by the interviewees that explicit this flexibility is the fact that the collaborators, who wish to study, are released from work in the physical environment of the company, as can be seen in E02 statement: "if the person wants to do a master degree abroad and wants to continue working with us, she will be able to continue [...]" (E02). This flexibility regarding education and the possibility of working at home represents an opportunity for women, who often need to balance their professional and personal lives (O'Neil et al., 2008).

E10 compares the way people perform their activities in traditional companies and how activities are developed in startups. The interviewee's report indicates a change in the job nature at startups, which loses the rigidity of the outlines fixed by job description in organizations. Acker (1990) indicates that the organization describes jobs in an abstract way, but besides that, these job characteristics serve as tools to reproduce gender inequality in organizations, because the characteristics and requirements of abstract 


\section{Manoel Bastos Gomes Neto, Lucas Emmanuel Nascimento Silva, Rebeca da Rocha Grangeiro e Catherine Esnard}

jobs exclude women when they implicitly report a male reality. Therefore, when at startups, female employees do not have activities explicitly defined and have more autonomy to perform tasks, the reproduction of assumptions about gender that are perpetuated by the abstract job are mitigated.

\footnotetext{
"because when I have a traditional company, [...] I work in the marketing sector and I have to do just that, I work in the production sector and I have to do just that, and the startup model is: I do that and all the other things. So, this mentality that exist an owner, that we ask in traditional companies, we know that it doesn't exist, it doesn't really exist within startups." (E10)
}

Also, in the context of comparing organizational cultures, E07 comments on the dynamism and agility of processes within a startup: "the development itself in startups is much faster than in any other company. Because, what we experience in a year, for example, is what a normal company, or a more traditional company, experiences in a few years" (E07). These agility and dynamism require a structure that is different from traditional organizations, the interviewees reinforce the existence of a flat hierarchy in startups: "[...] everything is very horizontal, there is not much verticality". (E04)

In the case of this new organization model, the structure leans towards horizontality and greater autonomy for employees (Freeman \& Engel, 2007). These characteristics demand more responsibility from self-managing teams and leaders have greater power in the promotion process (Williams et al., 2012). As indicated by E04, the role of leadership in startups is to direct the team: "We have leaders because at last we need to have them, as guides, we need someone to show the direction [...] they bring this vision and those directions. "(E04)

It is observed that in some startups women themselves strive to reduce this gender gap and strengthen the representation of female leaders. The interviewees emphasize that when they perceive a large number of men in the team, they prioritize to hire women, even though there is no explicit quota policy in the selection processes, as highlighted by E08: "What happens is that I prioritize. So we have a woman responsible to do this. I am the responsible one. Ah, there are already five men in the sector, than I said, "look, let's go after a woman!" (E08). E05 shows that: "(...) this demand for equality has not arisen now, but I think it has gained a lot of strength in recent years too, I think startups are more open to this (...)" (E05).

The interviewees confirmed that they participated in exclusively female events and conferences, which also aim to strengthen the female collective in startups. They commented that these events provide a safe space for discussion about experienced facts in everyday work-life. These conferences also enable the creation and strengthening of relationship networks, which is one of the main challenges for women's contemporary careers (Williams et al., 2012)

"[...] We often say that it is our safe place to [laughs] to let off stem about everything that happens in life and here, right? Personal stories ... or professional stories, it is a place that I feel I can share ... the difficult situations that I experienced, ... and I can ask for help for the women who are working with me, and I can tell them: oh, help me when it happens again or be aware and be careful for that it doesn't happen to you." (E03)

There are countless positive aspects of exclusively female conferences in startups in which positive messages are passed to women and it's perceived the formation of leaderships, but it is interesting to note that they can also have the negative consequence, like strengthening gender segregation and legitimizing the differences between men and women in these spaces (Hardey, 2019).

Regarding the motivations for working at startups, the interviewees highlighted the social factor as an important consequence of their work. In these organizations in early stages, the personal characteristics and social values of the entrepreneurs are very relevant (Low \& Abrahamson, 1997). E02 reports the execution of these activities: "[...] so I work here every day because I believe on it and because I really need to create something that will leave an impact wherever I am. So that's what motivates me the most, it's really making that difference" (E02). The literature on female entrepreneurship reinforces that the goals of these women are not only associated with economic gains (Jennings \& Brush, 2013). Female participation in this context, guided by 
motivations different from male ones, dynamizes the entrepreneurship ecosystem by providing new products, processes and forms of organization (Berger \& Kuckertz, 2016).

Traditional organizations have historically constructed barriers that hinder women's participation and their rise to senior management positions. In the context of startups, the interviewees indicated greater opportunity for growth and fewer barriers. In these organizations, job evaluation is performed differently. Performance appraisal in traditional companies reflects an organizational structure and a role model where gendered organization's values are consolidated and reproduced (Acker, 1990). In contemporary organizational models, performance evaluation has different outlines, in which the professional is assessed based on individual standards (Williams et al., 2012). Therefore, with differentiated job and job evaluation models, startups have a less unfair career plan system that offers greater growth opportunities for women.

"So, I see a huge opportunity for growth. In a traditional company there are barriers. Because there is a leader there, he will only stop being a leader when he dies, or retires. So you're stuck, you can't grow. Because you reach a point where you can't grow anymore." (E07)

Ratifying the testimony above, E04 exposes the possibility of assuming leadership positions in startups at a young age, at 21: "I think I would not have this opportunity if I were in a traditional company, or maybe I was still in an internship condition, learning a lot with other older people and maybe with men who were the leaders" (E04).

The research results presented here confirm this study assumption that characteristics intrinsic to the startups' organizational model favor the development of women career, especially if we compare the conditions found in startups with those experienced in traditional organizations models. Startups are a new organizational model in which creativity and innovation are fundamentals to their development. In order to improve creativity and innovation in their employees, startups developed features such as: more flexibility regarding work time and place; flatter hierarchy; and project-based work, what make job descriptions more flexible (Freeman \& Engel, 2007). The women career advancement is fostered by the flexibility on working hours, the possibility of working at home which allow women to balance their private and professional lives (O'Neil et al., 2008). To work based on projects is more favorable to women career advancement once they can show their competences in different areas depending on the project they working on. Evidence has shown that project-based organizations are very appropriated to the development of female career once mixed team provides the increase on creativity and innovation, thus, the women's participation in management positions in these organizations helps them to achieve competitive advantage and to improve their performance (Baker, Ali, \& French, 2019). Therefore, the project-based structure of startups are an opportunity to the women advancement in leadership positions.

The organization horizontal chart and the greater responsibilities and autonomy required allow women to assume activities and functions that improve their professional development. The social meaning of the work that they were doing and the support female groups they created are also characteristics that make startups fittable to women. To women is more important be in a job that make sense, a job in which they can see themselves doing great things to their community (Low \& Abrahamson, 1997).

\section{Barriers to professional development in startups}

Despite presenting itself as a more pleasant work environment for women, the numerical analysis shows that only $15.7 \%$ of Brazilian startups are founded by women (Abstartups, 2019), which is an evidence of vertical segregation in the sector (Lombardi 2006, 2017). The absence of gender parity in leadership positions was also detected by the professionals interviewed: "You can see how the number of men in leadership positions, taking care of startups is greater than the number of women" (E05). Entrepreneurship and technology occur in a gendered system and are impacted by it. Hence, in entrepreneurial and technological activity, there are lots of beliefs, behaviors, and roles associated with men and women. So entrepreneurship in startups is considered double gendered once they are organizations with a considerable technological basis (Kuschel, Ettl, Díaz-García, \& Alsos, 2020). 


\section{Manoel Bastos Gomes Neto, Lucas Emmanuel Nascimento Silva, Rebeca da Rocha Grangeiro e Catherine Esnard}

The low female representation in the board direction of startups is also reflected in the events promoted for professionals in the area. Men are more often invited to talk about their business and share their experiences, which perpetuates and reinforces gender discrimination, since it reproduces the image of man as the only one capable of succeeding in the business creation and management.

\footnotetext{
“(...) when I go to events, I always see men from startups talking and not women, so... sometimes I am called to an event to talk to (...) I am the annoying one, because if I am the only woman, I'll talk to the organizer afterwards 'look, it was nice to participate, but there was missing women"' (E05)
}

Still, when technological startups are examined, it is identified that women are a minority in these spaces (Hardey, 2019, Kuschel et al., 2017), which indicates horizontal segregation (Olinto, 2011, Gauche et al., 2013). Interviewees' testimonies show that they are aware of this segregation, as reported by E04: 'It is still very, very, very little. (...) Knowing other startups here in Fortaleza that are more focused on the technological area, (...) female participation is still minimal". There are areas of activity that are even more hostile to the female presence, such as technology, characterizing the horizontal segregation (Hardey, 2019, Olinto, 2011).

Even though organizational structures and systems are subject to relatively rapid changes, the individual attitudes and perceptions from the group of professionals that compose the organization do not keep the same pace (O'Neil et al., 2008), so that, even in organizations that favor flexibility and psychologically significant work may face barriers that slow or prevent the women professional development. The obstacles that exist for women in the process of financial resources or bank credit are barriers examples (Bigelow et al., 2014; Coleman \& Robb, 2009), as portrayed by E03, when her co-worker went to the bank to open at her place a company account: "when she (...) went to the bank to open an account (...) the manager told ber to call her husband, to be able to open an account for her". 'The same interviewee reports that the problems remain even after opening the account and, in several situations, she needed to call a male colleague to solve the company's problems with the financial institution, which refused to resolve with her: "several times (...) she had to call some boys to solve some problems, because she couldn't solve it herself". The relationship with financial institutions imposed discriminatory barriers for women in simpler procedures than asking for fundings (Kanze et al., 2018; Bigelow et al., 2014; Colleman \& Robb, 2009). This kind of barrier is classified as the second wall in glass walls metaphors (Santos et al., 2016).

The literature presents some obstacles that women have to achieve professional recognition and financial independence, with emphasis on the negative attitudes of clients and co-workers (Santos et al., 2016). The E09 reports difficulties in contact with customers. By working directly with the external public, in the sales sector, the interviewee realizes that some of them imply affective interests at the negotiation time: "I am a saleswoman, what I realize is that sometimes the person asks: 'oh but how old are you?', (...) T'm looking your profile picture here, you are a pretty girl".

Besides the costumer's sexualized comments about their physical appearance, another problem evidenced by the interviewees was the fact that some clients question and underestimate their skills due to the fact that they are women and that is why they need to legitimize their skills and abilities constantly. As can be seen in the E08 speech: "it was me and three other boys, (...) there were cases when I was presenting my product and the costumer said 'oh, I want to talk to the developer', although in my presentation there is saying that I am a developer ".

"I felt a little difficult for clients to trust me, especially when there were a lot of men because. I have that young face, so (laughs) I always noticed how they always distrust, I needed to work a few months with them so they could give me more credit". (E05)

These testimonies reflect a barrier experienced by women who are not recognized for their professional skills when working in traditionally male areas (Hardey, 2019, Santos et al., 2016).

It is also noted that, even though they occupy a position at the top of the organization, women face difficulties in being heard and feeling integrated into discussions with coworkers, as mentioned in E04: 
"you are in the meeting, for example, of leaders (...) and it is as if they understand each other in a completely different language. (...) I, in the leadership position, cannot get into the conversation and, indeed, have my idea heard".

There is a male language code that excludes women from dialogues. In addition, the male co-workers disallow female discourse by underestimating or devaluing the arguments she exposes, so that the exclusion from the relationship network, which is strongly masculine, it's not just because women can not fully grasp what is being said, but also because they have difficult to make themselves understood. The interviewee cannot make herself understood, cannot be heard and even though she is present at the meeting, given that, through her competence, she occupies a leadership position, she is excluded from the dialogue because she is prevented from receiving and giving messages. In order to change this reality, women adopt a less feminine posture. Interviewee E03 portrays this situation: "(...) sometimes we have to adopt a serious attitude. Sometimes we have to be short and sweet. Yeah ... Sometimes we have to say: ob, you didn't let me finish". This finding is confirmed by scientific papers already published about traditional organizations and point how women adopted male characteristics as a strategy to ensure a form of interaction, to maintain respect and to soften the women image of fragility (Cursino \& Carvalho Neto, 2015).

However, the assertive behavior of trying to expose one's own idea and being heard is not unanimous among startups female professionals, so that some of them feel gender segregation so strongly that they prefer not to attend the mixed events promoted by professionals in the field, as suggested by E02:

\footnotetext{
“(...) I need to go out inviting almost personally each woman, I send a message to each one of the women I know in order to have a greater participation. (...) they are afraid to talk, to speak because (...) there is a lot of startuper language (...) they already feel a little that they will not be able to follow". (E02)

"And also I have another event (...) for happy hour and for startuper, which is exactly just for networking, just for exchange, this is more to relax and to take advantage of the space to be able to make network and (...) we saw a lot of men present, and we didn't see women present $(. .$. "(E02)
}

As perceived by E02, there is low female participation in formal and informal mixed meetings for startup professionals. The reports show evidences that women exclude themselves and/or are excluded from these moments of dialogue and interaction, as they do not understand the predominant language and, about the happy hours, it is worth mentioning that in the cultural context of the analyzed city, happy hours are still considered a masculine space. Thus, the masculinization of the environment and language is used as barriers or challenges to be overcome by women to advance their careers in startups. The barriers imposed by co-workers and others entrepreneurs is classified by Santos et al. (2016) as the third wall of the metaphor. They determine behaviours, language and tasks that both men and women must perform in workplace.

The family barrier pointed out by Santos et al. (2016) was also identified among the study participants. The E06 highlighted the ex-partner's lack of incentive and his discomfort in face of her professional success: "And it is the challenge of having a partner who also (...) supports one hundred percent, and not just for the sake of saying it". Santos et al. (2016) state that the entrepreneurial career maximizes the financial independence of women. Some men do not know how to deal with the autonomy of their wives and do not support them when they perceive their professional success (Santos et al., 2016; Cursino \& Carvalho Neto, 2015). In some cases, the entrepreneur's parents slow down or even try to block her advancement what constitutes the second type of glass wall imposed on women at work (Santos et al., 2016).

In view of the discussions presented in this section, it is suggested that the second assumption of the research was confirmed, because even in new organizational models, women face gender barriers that emerge from the relationship with peers, customers, banking institutions and even in relation to their husbands, so many complex forces are combine to hinder systematically women's advancement in academia. Due to the naturalization of male supremacy in organizations, many discriminatory behaviors are naturalized and therefore difficult to be noticed. The invisibility or difficult perception of these 


\section{Manoel Bastos Gomes Neto, Lucas Emmanuel Nascimento Silva, Rebeca da Rocha Grangeiro e Catherine Esnard}

obstacles, which are experienced by women throughout their career, allows an association of this context with the glass wall image (Miller et al., 1999; Santos et al., 2016), the metaphor addressed in this article.

\section{Conclusion}

This work aimed to identify and discuss obstacles and career opportunities for women who work in leadership positions in startups. The results indicate that this new organizational model has more flexibility with regard to schedules, home office and functions performed. Dynamism and agility, typical of startups processes, influence and are influenced by the horizontal organizational hierarchy and by greater autonomy given to employees. In view of the current socio economic scenario that the world is facing due to COVID-19 pandemic, the adversities for women professional advancement have become even greater. The measures of social distance have directly impacted on traditionally female sectors and the closure of schools and day care centers have increased the women's responsibilities as housekeeper and the ones who take care of the children.

In face of the pandemic, companies are adopting strategies and incorporating a flexible work model, similar to startups, that are likely to be maintained even after the end of social distance (Alon, Doepke, Olmstead-Rumsey, \& Tertilt, 2020). The adoption of startup's organizational structure model may contribute to create an environment more conducive to women. Besides the women career disadvantages in the health crisis (Cohen \& Hsu, 2020; Donner, 2020; Donadio, 2020), we can observe some positive changes in men's behavior that are also taking on family responsibilities. These changes in behavior and organizational structures influence the break of social norms, in addition to creating a culture that promotes and contributes to gender equality at work.

Among the interviewed professionals, it was noticed that there is an incentive to strengthen the female group, which can be observed through flexible schedules for women who wish to have children or continue their studies. They also demonstrated to prioritize hiring women, when the team had a majority of men. In order to support each other, they developed events, in and out the organization, to reflect and discuss about facts experienced within their companies, building a supportive environment. However, the events at the same time that strengthen the female collective, further segregate the possible spaces for men and women (Hardey, 2019).

Although the results indicate a culture favorable to the participation and rise of women in leadership positions, this research also identified some barriers that persist and hinder female professional development in this new organizational model. Although startups are structurally less bureaucratic, more flexible and adopt a horizontal management, it is still an environment in what "glass walls" persist for women, that are presented in relations with banking institutions, clients, co-workers, leaders and directors of other startups and even with people living in their private life sphere.

The opportunities and challenges presented help to understand the benefits of the new organizational model and the paths that need to be further explored in the search for gender equality in organizations. Nevertheless, a limit of this study refers to the gender approach used, which was based on a binary perspective, but which has a historical social construction that permeates masculinity and femininity, thus, we suggest that new studies consider the complexity of the gender dimension and its diverse perspectives and discuss its role in startups. The data collection restricted in Fortaleza/CE city may also include a limitation, because the results despite revealing a conjuncture common to other contexts should not be generalized. Thus, new studies can be carried out in other regions considered as startups hubs.

In addition, future studies may reinforce discussions based on startups that have an advanced organizational culture and those that have a market value greater than one billion dollars and are classified as unicorn startups. Moreover, new research should try to contact female startup founders, in order to 
capture possible challenges in relation to obtaining business financing. It is hoped that this research can contribute to the understanding of the logic of women's professional performance in new organizational models, presenting the main challenges and opportunities they experience in startups. There's still a lack of scientific literature concerning this organizational context, especially in Brazil, and the results presented can raise discussions about the female career in these organizations and how new organizational structures can foster gender equality.

\section{References}

Acker, J. (1990). Hierarchies, jobs, bodies: A theory of gendered organizations. Gender \& society, 4(2), 139158. https://doi.org/10.1177/089124390004002002

Alon, T. M., Doepke, M., Olmstead-Rumsey, J., \& Tertilt, M. (2020). The impact of COVID-19 on gender equality (No. w26947). National Bureau of Economic Research. https://doi.org/10.3386/ w26947

Baker, M., Ali, M., \& French, E. (2019). The impact of women's representation on performance in project-based and non-project-based organizations. International Journal of Project Management, 37(7), 872-883. https://doi.org/10.1016/j.ijproman.2019.06.001

Berger, E. S., \& Kuckertz, A. (2016). Female entrepreneurship in startup ecosystems worldwide. Journal of Business Research, 69(11), 5163-5168. https://doi.org/10.1016/j.jbusres.2016.04.098

Bigelow, L., Lundmark, L., McLean Parks, J., \& Wuebker, R. (2014). Skirting the issues: Experimental evidence of gender bias in IPO prospectus evaluations. Journal of Management, 40(6), 1732-1759. https://doi.org/10.1177\%2F0149206312441624

Cohen, P. (2020, June 4). Pandemic Could Scar a Generation of Working Mothers. Retrieved June 4, 2020, from https://www.nytimes.com/2020/06/03/business/economy/coronavirus-workingwomen.html

Coleman, S., \& Robb, A. (2009). A comparison of new firm financing by gender: evidence from the Kauffman Firm Survey data. Small Business Economics, 33(4), 397. https://doi.org/10.1007/s11187-0099205-7

Cursino, A. M. C. ; Carvalho Neto, A. (2015). O estilo de gestão da mulher executiva brasileira: o feminino no masculino ou o masculino no feminino?. In: Andrade, J. O.; Carvalho Neto, A.. (Org.). (2015). Mulheres Profissionais e suas carreiras sem censura: estudo sob diferentes abordagens. São Paulo: Editora Atlas, p. 137-153. https://doi.org/10.1590/S1415-65552002000200011

Donadio, R. (2020, May 28). The Coming Setback for Women in the Workplace. Retrieved June 5, 2020 , from https://www.theatlantic.com/international/archive/2020/05/france-women-workplacecoronavirus-pandemic/612136/

Donner, F. (2020, May 20). How Women are Getting Squeezed by the Pandemic. Retrieved June 8, 2020 , from https://www.nytimes.com/2020/05/20/us/women-economy-jobs-coronavirus-gender.html

Estado, A. (2020, May 15). Taxa de desemprego das mulheres é 39,4\% superior à dos homens, diz IBGE. Retrieved June 5, 2020, from https://www.infomoney.com.br/economia/taxa-de-desemprego-dasmulheres-e-394-superior-a-dos-homens-diz-ibge/

Flick, U. (2008). Introdução à pesquisa qualitativa. Artmed editora.

Freeman, J., \& Engel, J. S. (2007). Models of innovation: Startups and mature corporations. California Management Review, 50(1), 94-119. https://doi.org/10.2307\%2F41166418 


\section{Manoel Bastos Gomes Neto, Lucas Emmanuel Nascimento Silva, Rebeca da Rocha Grangeiro e Catherine Esnard}

Gauche, S., Verdinelli, M. A., \& Silveira, A. (2013). Composição das equipes de gestão nas universidades públicas brasileiras: segregação de gênero horizontal e/ou vertical e presença de homossociabilidade. Encontro Nacional de Gestão de Pessoas e Relações de Trabalbo, 4.

Guillaume, C., \& Pochic, S. (2009). What would you sacrifice? Access to top management and the worklife balance. Gender, Work \& Organization, 16(1), 14-36. https://doi.org/10.1111/j.14680432.2007.00354.x

Hall, D. T. and P. H. Mirvis. (1995). The New Career Contract: Developing the Whole Person at Midlife and Beyond, Journal of Vocational Behavior 47(3), 269- 289. https://doi.org/10.1006/jvbe.1995.0004

Hardey, M. (2019). Women's leadership and gendered experiences in tech cities. Gender in Management: An International Journal. https:// doi.org/10.1108/GM-05-2018-0048

Instituto Brasileiro de Governança Corporativa (IBGC). (2015). IBGC incentiva a presença de mulheres na governança corporativa. Disponível em <http://www.ibgc.org.br/index.php/19412/IBGCincentiva-a-presenca-de- mulheres-na-Governanca-Corporativa $>$

Kuschel, K., Ettl, K., Díaz-García, C., \& Alsos, G. A. (2020). Stemming the gender gap in STEM entrepreneurship-insights into women's entrepreneurship in science, technology, engineering and mathematics. International Entrepreneurship and Management Journal, 16(1), 1-15. https://doi.org/10.1007/s11365-020-00642-5

Kuschel, K., Lepeley, M. T., Espinosa, F., \& Gutiérrez, S. (2017). Funding challenges of Latin American women start-up founders in the technology industry. Cross Cultural \& Strategic Management, 24(2), 310-331. https://doi.org/10.1108/CCSM-03-2016-0072

Lombardi, M. R. (2006). Engenheiras brasileiras: inserção e limites de gênero no campo profissional. Cadernos de pesquisa, 36(127), 173-202. https://doi.org/10.1590/S0100-15742006000100008

Lombardi, M. R. (2017). Engenheiras na construção civil: a feminização possível ea discriminação de gênero. Cadernos de pesquisa, 47(163), 122-146. https://doi.org/10.1590/198053143619

Lopes Filho, R. F., Paiva, L. E. B., \& Lima, T. C. B. (2019). Motivações e Perspectivas Futuras de Empreendedores de Startups. BASE - Revista de Administração e Contabilidade da UNISINOS, 16(4), 489522. https://doi.org/10.4013/base.2019.164.01

Low, M. B., \& Abrahamson, E. (1997). Movements, bandwagons, and clones: Industry evolution and the entrepreneurial process. Journal of business venturing, 12(6), 435-457.

Matos, F. (2017, outubro). Qual a região campeã em densidade de Startups no Brasil? Você vai se surpreender. Estadão, out., 2017. Recuperado em 15 fevereiro, 2020, de: http://link.estadao.com.br/blogs/felipematos/qual-a-regiao-campea-em-densidade-de-Startupssurpreender/?utm_source $=$ meio\&utm_medium $=$ email. no-brasil-voce-vai-se-

Mickey, E. L. (2019). When Gendered Logics Collide: Going Public and Restructuring in a High-Tech Organization. Gender \& Society, 33(4), 509-533. https://doi.org/10.1177\%2F0891243219830944

Micklas, K. (2020, May 28). Coronavirus pandemic forces millions of working women into "impossible" roles. Retrieved June 5, 2020, from https://www.cbsnews.com/news/coronavirus-pandemic-forcesmillions-of-working-women-into-impossible-roles/

Miller, W., Kerr, B., \& Reid, M. (1999). A national study of gender-based occupational segregation in municipal bureaucracies: Persistence of glass walls?. Public Administration Review, 218-230. https://doi.org/10.2307 / 3109950

Morrison, A. M.; Von Glinow, M. A. (1990). Women and minorities in management. American Psychological Association, 45 (2): 200-208,1990. https://psycnet.apa.org/doi/10.1037/0003-066X.45.2.200 
O’Neil, D. A., Hopkins, M. M., \& Bilimoria, D. (2008). Women's careers at the start of the 21st century: Patterns and paradoxes. Journal of Business Ethics, 80(4), 727-743. https://doi.org/10.1007/s10551-0079465-6

Olinto, G. (2011). A inclusão das mulheres nas carreiras de ciência e tecnologia no Brasil. Inclusão Social, $5(1)$.

Sabharwal, M. (2015). From glass ceiling to glass cliff: Women in senior executive service. Journal of Public Administration Research and Theory, 25(2), 399-426. https://doi.org/10.1093/jopart/mut030

Santos, C. M. M., Carvalho Neto, A., Caeiro, M., Versiani, F., \& Martins, M. G. (2016). As mulheres estão quebrando as três paredes de vidro? Um estudo com empreendedoras mineiras. Revista Economia \& Gestão, 16(45), 126-149. https://doi.org/10.5752/P.1984-6606.2016v16n45p126

Smith, P., Caputi, P., \& Crittenden, N. (2012). A maze of metaphors around glass ceilings. Gender in Management: An International Journal, 27 (7), 436-448. https://doi.org/10.1108/17542411211273432

Taub, A. (2020, May 18). Why Are Women-Led Nations Doing Better With Covid-19? Retrieved June 5, 2020, from https://www.nytimes.com/2020/05/15/world/coronavirus-women-leaders.html

Williams, C. L., Muller, C., \& Kilanski, K. (2012). Gendered organizations in the new economy. Gender \& Society, 26(4), 549-573. https://dx.doi.org/10.1177\%2F0891243212445466 